\title{
Temperature and larval development of Carcinus maenas (Decapoda) in the laboratory; predictions of larval dynamics in the sea
}

\author{
Ralph R. Dawirs \\ Biologische Anstalt Helgoland, Meeresstation, D-2192 Helgoland, Federal Republic of Germany
}

\begin{abstract}
Larvae of Carcinus maenas (L.) (Decapoda, Brachyura, Portunidae) were reared in the laboratory from hatching to metamorphosis. Developmental times of subsequent stages at different constant temperatures $\left(6,12,12.5,18,25^{\circ} \mathrm{C}\right)$ were recorded. Temperature-dependent development of each larval stage can be expressed by a power function. A model is presented which combines these results with the long-term mean temperature curve of Helgoland waters (North Sea). Hence prediction is possible of occurrence and presence of $C$. maenas larvae in the natural environment relative to their hatching date. On the basis of main hatching activities in nature, qualitative larval dynamics in Helgoland waters are discussed. To test the usefulness of the model, $C$. maenas larvae were reared in the laboratory from hatching to metamorphosis under simulated varying in situ temperatures. Results of this experiment correspond very well with model predictions.
\end{abstract}

\section{INTRODUCTION}

It is well established that temperature is one of the most important environmental factors in nature. Biochemical and physiological reactions have optimum temperature ranges, beyond which basic mechanisms of living organisms cease to function. Consequently, much effort has been undertaken to elucidate relations between temperature and development, growth, and metabolism of decapod crustacean larvae in the marine environment (for references see Dawirs 1982a). In most of these investigations the range of possible physiological responses was related to constant temperature conditions.

Dynamic processes, however, play an important role. Environmental temperatures in boreal seas, for example, reveal short-time and seasonal fluctuations. Many dynamic processes are controlled by the characteristic annual course of varying water temperature.

To analyse larval dynamics of Carcinus maenas in Helgoland waters, 2 questions were posed: (1) To what extent is the duration of larval development influenced by water temperature? (2) Is it possible to predict the occurrence and presence of subsequent larval stages in nature relative to the date of hatching? To answer these questions, $C$. maenas larvae were reared from hatching to metamorphosis at several constant temperatures. Data from this temperature-dependent larval development were combined with data from the longterm mean temperature curve of Helgoland waters. Some work has already been done on the basis of this concept (Anger \& Nair 1979, Dawirs 1979, 1982a, Harms 1982, Anger 1983).

\section{MATERIAL AND METHODS}

Obtaining and handling of larvae. Gravid Carcinus maenas females were collected from the rocky intertidal region of northern Helgoland and taken to the laboratory. Maintenance of ovigerous crabs, and larval collecting and handling methods, were performed as described by Dawirs (1982b). A total of 500 larvae were reared under both constant and variable temperature conditions.

Individual larvae were kept in small glass vials containing $20 \mathrm{ml}$ of filtered $(1 \mu \mathrm{m})$ natural sea water from Helgoland ( 31 to $33 \% \mathrm{~S}$ ), in constant $6,12,12.5,18$ or $25^{\circ} \mathrm{C}$. They were fed newly-hatched brine shrimp nauplii, Artemia spp. (ca 10 nauplii $\mathrm{ml}^{-1}$ )

Temperature varied gradually to simulate the annual course of in situ temperature. Fig. 1 illustrates 


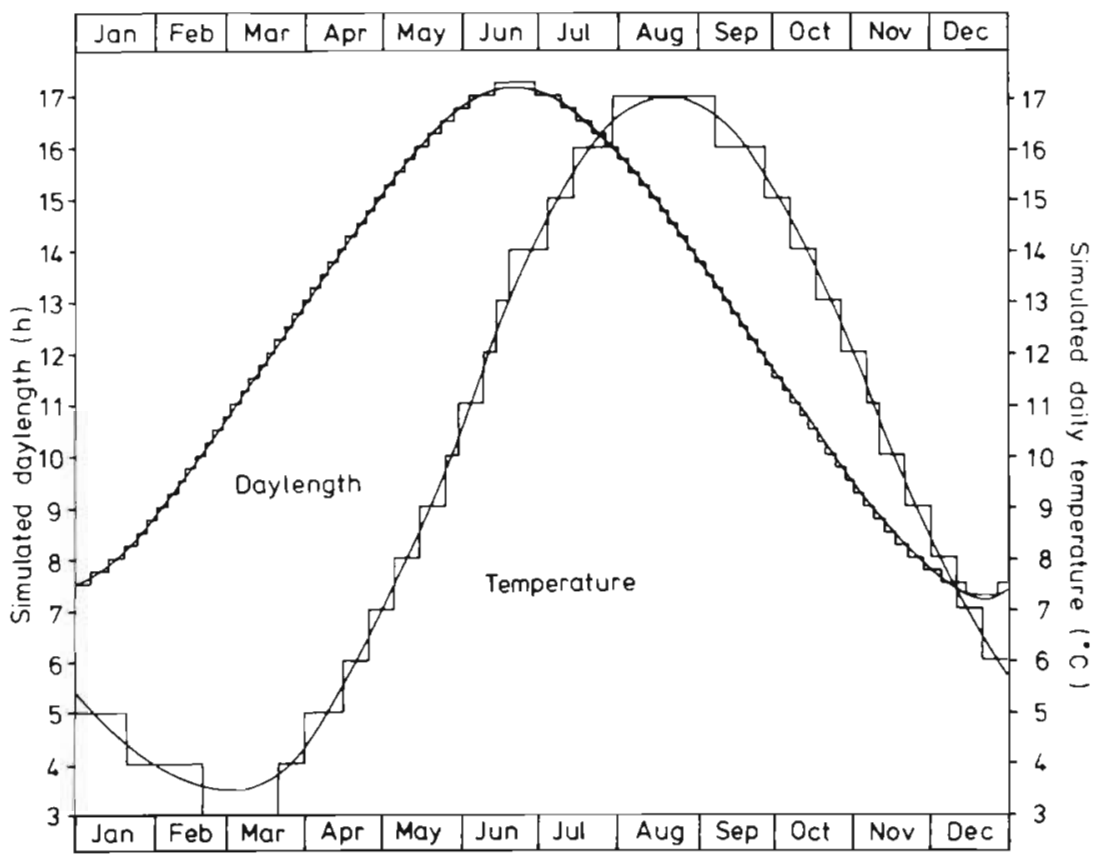

Fig. 1. Design of temperature and daylength regulation (steps) of the experimental chamber. Curves illustrate the simulated annual course of temperature and day length these changes together with the resulting idealized temperature curve. Natural daylength was simulated concurrently by gradual changing of daily light-dark ratios (Fig. 1). Larvae reared under these conditions originated from females which had also been kept in this temperature cabin. Thus egg incubation also took place under the simulated natural temperature regime.

Simulating larval dynamics in the sea using laboratory and field data. The long-term mean water temperature near Helgoland increases from about $4^{\circ} \mathrm{C}$ in February to about $17^{\circ} \mathrm{C}$ in August, and decreases thereafter. Using data in Weigel (1978), the course of daily water temperature can be expressed by the following parabolae:

Jan 1st - Jun 14th: $T=5.6067-0.0785 d+0.00074 d^{2}$ Jun 15th - Oct 14th:

Oct 15th - Dec 31st:

$$
\mathrm{T}=-36.7493+0.4630 \mathrm{~d}-0.00099 \mathrm{~d}^{2}
$$

$$
T=68.6692-0.2562 \mathrm{~d}+0.00023 \mathrm{~d}^{2}
$$

where $\mathrm{T}=$ temperature $\left({ }^{\circ} \mathrm{C}\right) ; \mathrm{d}=$ day of the year $(1 \mathrm{to}$ 365) (Anger 1983).

Estimation of in situ duration of larval development was made as follows: (1) Field temperature on the day of hatching $(\mathrm{T})$ is determined by 1 of the above 3 parabolae. (2) This temperature enters the power function describing temperature dependent developmental duration of zoea 1 (Table 1). By this means, theoretical stage duration is calculated on the assumption that field temperature ( $\mathrm{T}$ ) remains constant. (3) One d after hatching, water temperature in the field becomes either somewhat warmer or cooler, depending on season. The calculated theoretical stage duration there-
Table 1. Carcinus maenas. Temperature-dependent development of larvae described by power functions. D: development duration (d); $\mathrm{T}$ : water temperature $\left({ }^{\circ} \mathrm{C}\right)$; a: constant; b; regression coefficient; $r$; correlation coefficient; $p$ : level of significance

\begin{tabular}{|lcccc|}
\multicolumn{5}{c}{$\ln \mathrm{D}=\mathrm{a}-\mathrm{b} \ln \mathrm{I}$} \\
& $\mathrm{a}$ & $\mathrm{b}$ & $\mathrm{r}$ & $\mathrm{p}<$ \\
\hline Zoea 1 & 5.75 & -1.45 & -0.951 & $10^{-5}$ \\
Zoea 2 & 5.68 & -1.47 & -0.942 & $10^{-4}$ \\
Zoea 3 & 6.39 & -1.70 & -0.979 & $10^{-6}$ \\
Zoea 4 & 6.86 & -1.79 & -0.976 & $10^{-6}$ \\
Megalopa & 6.63 & -1.44 & -0.947 & $10^{-4}$ \\
\hline
\end{tabular}

fore will be slightly shorter or longer. (4) The real stage duration on the basis of varying field temperature is then calculated by adding the reciprocal values of the theoretical durations in different subsequent daily mean water temperatures. Stage duration equals the number of days once this summation reaches zero. (5) The calculated mean temperature on the following day then enters the power function describing temperature-dependent development of the zoea 2 (Table 1). The same procedure as for zoea 1 is applied. In this way stage durations of all 5 subsequent larval stages are determined for same-day hatched larvae. (6) Calculations in steps 1 to 5 were repeated for every subsequent hatching day between Day 140 and Day 273 of the year. (7) Calculations in steps 1 to 6 were repeated for theoretical field temperatures lying consistently $0.5 \mathrm{C}^{\circ}$ above and below the long-term daily mean 
Table 2. Carcinus maenas. Development duration of larval stages in different constant temperatures. $\bar{x}$ : mean values in days, $\pm 95 \%$ confidence intervals; $\%$ : cummulative mortality; n: number of individuals

\begin{tabular}{|c|c|c|c|c|c|c|c|c|c|c|c|c|c|c|c|c|}
\hline & \multicolumn{3}{|c|}{ Zoea 1} & \multicolumn{3}{|c|}{ Zoea 2} & \multicolumn{3}{|c|}{ Zoea 3} & \multicolumn{3}{|c|}{ Zoea 4} & \multicolumn{3}{|c|}{ Megalopa } & \multirow[b]{2}{*}{$\mathrm{n}$} \\
\hline & $\bar{x}$ & \pm & $\%$ & $\overline{\mathrm{x}}$ & \pm & $\%$ & $\bar{x}$ & \pm & $\%$ & $\bar{x}$ & \pm & $\%$ & $\bar{x}$ & \pm & $\%$ & \\
\hline \multirow[t]{3}{*}{$12^{\circ} \mathrm{C}$} & 8.80 & 0.32 & 0 & 8.12 & 0.34 & 0 & 9.04 & 0.58 & 4 & 11.57 & 0.26 & 8 & 27.55 & 0.81 & 12 & 25 \\
\hline & 9.63 & 0.30 & 4 & 9.00 & 0.39 & 8 & 10.09 & 0.65 & 8 & 13.04 & 0.33 & 8 & 19.53 & 0.86 & 24 & 25 \\
\hline & 8.93 & 0.23 & 2 & 8.02 & 0.33 & 6 & 8.78 & 0.39 & 10 & 11.31 & 0.32 & 10 & 20.37 & 0.75 & 46 & 50 \\
\hline $12.5^{\circ} \mathrm{C}$ & 7.18 & 0.11 & 2 & 6.47 & 0.20 & 2 & 7.19 & 0.21 & 4 & 9.58 & 0.16 & 6 & 17.63 & 0.50 & 8 & 50 \\
\hline \multirow[t]{6}{*}{$18^{\circ} \mathrm{C}$} & 6.05 & 0.47 & 20 & 4.89 & 0.23 & 28 & 4.44 & 0.25 & 28 & 5.50 & 0.31 & 28 & 13.29 & 0.87 & 32 & 25 \\
\hline & 4.32 & 0.20 & 0 & 3.64 & 0.24 & 0 & 4.00 & 0.32 & 0 & 4.56 & 0.36 & 0 & 13.38 & 0.85 & 36 & 25 \\
\hline & 4.63 & 0.24 & 14 & 4.10 & 0.13 & 16 & 4.62 & 0.29 & 16 & 8.93 & 0.14 & 22 & 12.45 & 0.46 & 38 & 50 \\
\hline & 4.92 & 0.27 & 2 & 4.44 & 0.51 & 8 & 4.35 & 0.61 & 8 & 5.23 & 0.55 & 40 & 12.11 & 0.81 & 82 & 50 \\
\hline & 4.07 & 0.07 & 8 & 3.50 & 0.18 & 8 & 4.04 & 0.23 & 8 & 5.32 & 0.35 & 12 & 12.27 & 0.66 & 32 & 50 \\
\hline & 4.37 & 0.22 & 2 & 3.94 & 0.20 & 4 & 3.98 & 0.29 & 6 & 5.09 & 0.30 & 10 & 13.80 & 0.71 & 30 & 50 \\
\hline $25^{\circ} \mathrm{C}$ & 3.07 & 0.08 & 16 & 3.12 & 0.18 & 18 & 2.78 & 0.23 & 20 & 3.44 & 0.25 & 28 & 5.81 & 0.55 & 58 & 50 \\
\hline
\end{tabular}

temperature. (8) All simulated developmental durations were rounded to full days in this paper.

The present model is based on the simplified assumption that only temperature acts on larval dynamics. By this method stage and total duration of larval development in the field can be simulated and predicted as a function of hatching date and in situ temperature.

\section{RESULTS}

\section{Temperature and larval development in the laboratory}

Larvae of Carcinus maenas were reared successfully at constant water temperatures between 12 and $25^{\circ} \mathrm{C}$. Data from 11 rearing experiments were used to verify temperature dependence in larval development (Table 2). Relations between temperature and stage duration can best be described by power functions (Table 1; Fig. 2). At $6^{\circ} \mathrm{C}$ zoea 1 larvae did not moult to the zoea 2 .

\section{Predictions of larval dynamics in the field}

To estimate the beginning of the hatching season, egg-carrying Carcinus maenas females were kept under a simulated in situ temperature regime. Larvae began hatching on 27 May when the water temperature reached $10^{\circ} \mathrm{C}$. The present temperature model (see 'Material and Methods') predicts that, in spring, $10^{\circ} \mathrm{C}$ is reached on Day 147 (i.e. 27 May).

The hatching season is assumed to last about $133 \mathrm{~d}$, between 20 May and 30 September (Fig. 3). Larvae which hatch during this period will be exposed to in

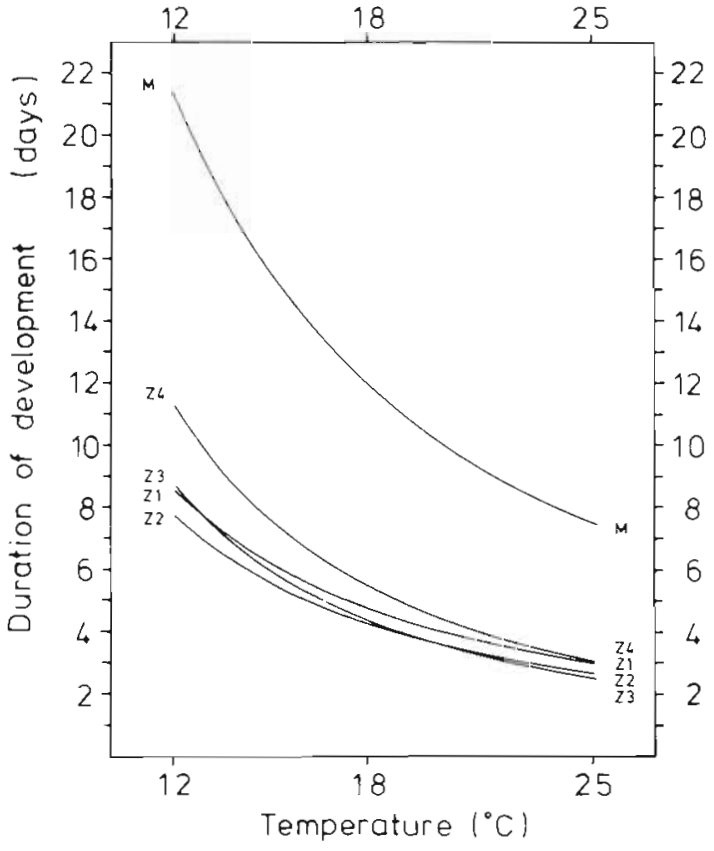

Fig. 2. Carcinus maenas. Temperature-dependent larval development. Regressions are given in Table 1. Z1: zoea 1 etc; $M$ : megalops

situ temperatures in which laboratory rearing was successful.

Larvae which hatch early in the year need more time to metamorphose than later larvae (up to Aug), since the in situ temperature is increasing. Larvae released on 20 May moult to the first juvenile crab stage after about $55 \mathrm{~d}(14 \mathrm{Jul})$. Later, development accelerates to a minimum of $36 \mathrm{~d}$ for larvae released between 20 July and 19 August. These larvae are therefore predicted to metamorphose between 25 August and 24 September, respectively. During this time the in situ temperature 


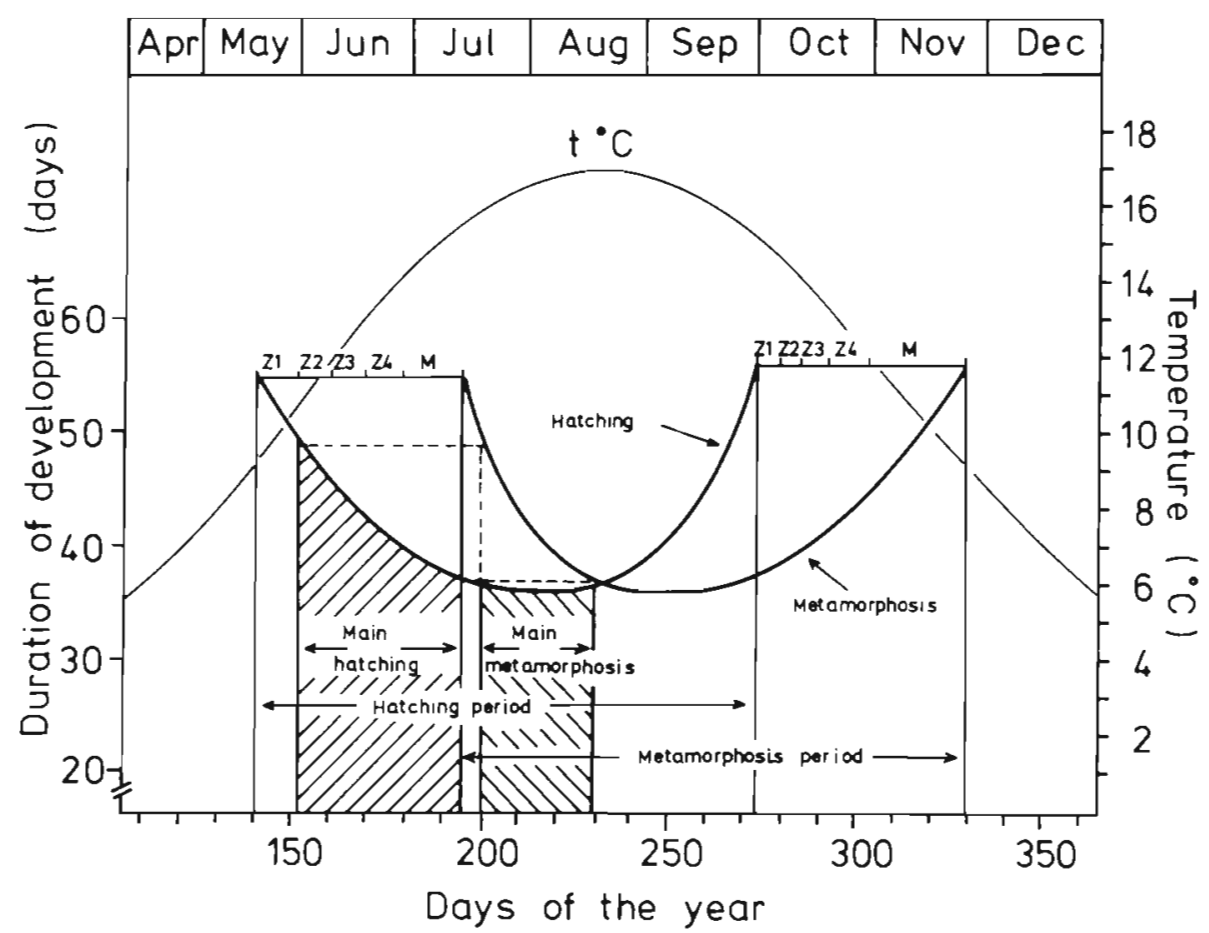

Fig. 3. Carcinus maenas. Prediction of temperature-dependent larval development in the field. Between 20 May and 30 September the hatching curve for subsequent days of hatching (abscissa) gives duration of total larval development (ordinate). Using the metamorphosis curve, duration of development (ordinate) leads to days of settling (abscissa); for example, dotted lines lead to a period of main metamorphosis (end of May to mid-Jul), relative to an assumed period of main hatching activities (mid-Jul to mid-Aug). $t^{\circ} \mathrm{C}$ : yearly long-term mean temperature curve; $\mathrm{Z} 1$ : zoea 1 etc.; $M$ : megalops

reaches its maximum on 19 August. Larvae which hatch later in the year show an increasing delay in development, since the mean daily field temperature is decreasing. Larvae occurring in the plankton at the end of the assumed hatching season on 30 September, accomplish development after about 56 d, i.e. at the end of November. Meanwhile daily in situ water temperature drops from about 15.3 to $9.2^{\circ} \mathrm{C}$ (Fig. 3).

Carcinus maenas larvae which hatch on 21 May and 29 September, for example, are predicted to develop over about $54 \mathrm{~d}$ in the plankton before they metamorphose (Fig. 3). However, as the model shows, developmental durations of subsequent larval stages vary in proportion to the total length of larval life relative to the date of hatching (Fig. 4). Megalops from the assumed 21 May hatch are predicted to require $16 \mathrm{~d}$ to metamorphose, which takes some $30 \%$ of the total larval life span in the field. Megalops from the 29 September hatch, however, will need $25 \mathrm{~d}$ to metamorphose, which takes almost $50 \%$ of total larval life span in the field. Different field temperature dynamics during in situ development of both hatches are responsible for this variation. In the first instance field temperature rises from about 14.2 to $15.6^{\circ} \mathrm{C}$; in the second, it falls from about 12.3 to $9.5^{\circ} \mathrm{C}$.

In Helgoland waters Carcinus maenas start hatching during late May. For larvae released between 20 and 30 May, the present model predicts occurrence of subsequent larval stages within the following periods: 31 May to 8 June (zoea 2), 9 June to 16 July (zoea 3), 18 to 24 June (zoea 4 ), 28 June to 3 July (megalops)

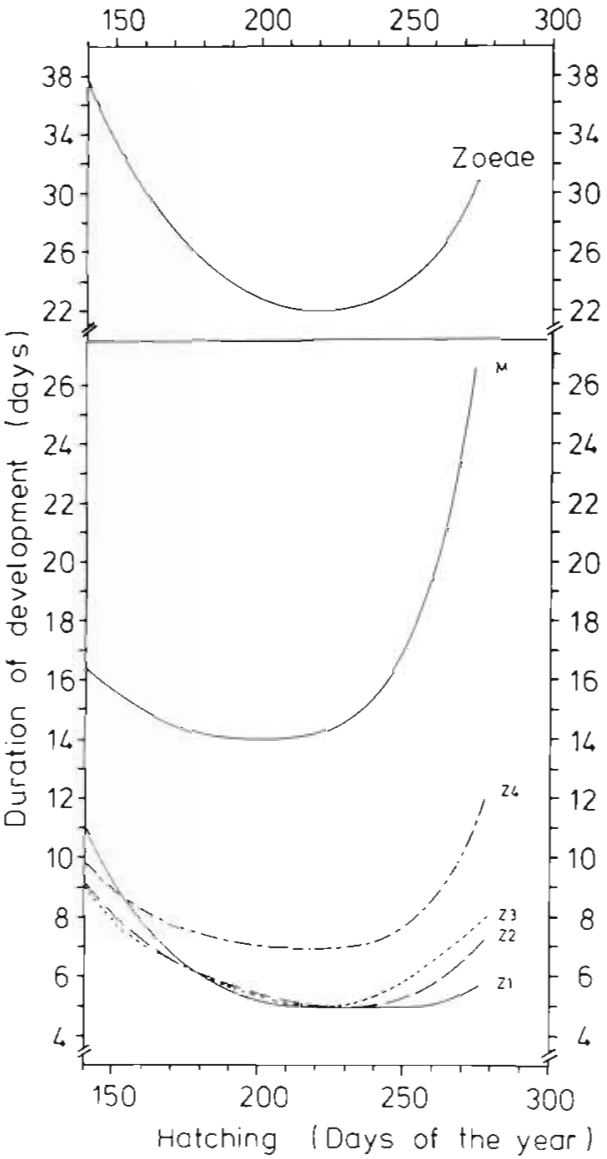

Fig. 4. Carcinus maenas. Prediction of temperature-dependent larval development in the field, with reference to subsequent larval stages, zoea 1 (Z1) to megalops (M) 


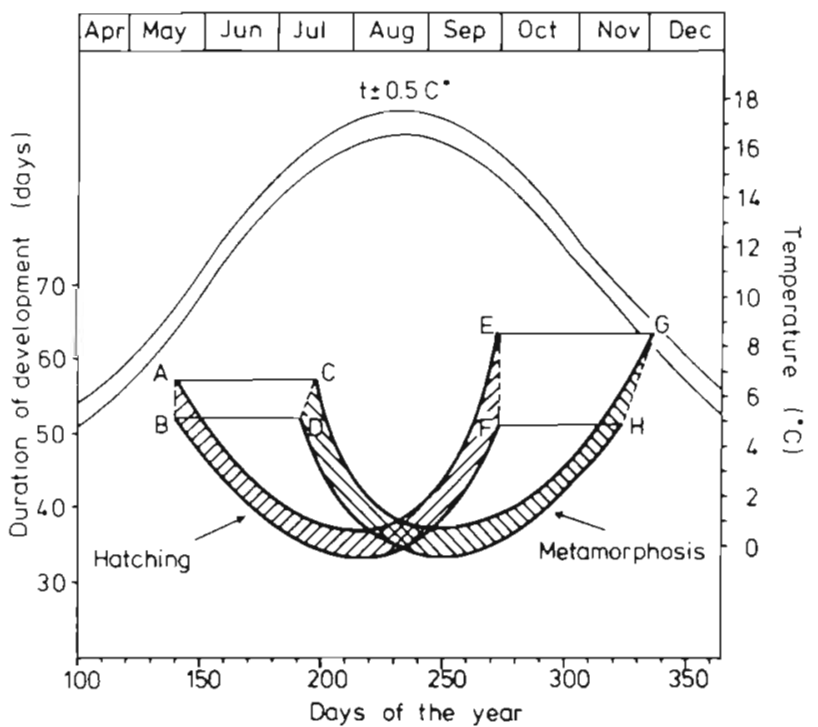

Fig. 5. Carcinus maenas. Prediction of temperature-dependent larval development in the field, with reference to deviations of $\pm 0.5 \mathrm{C}^{\circ}$ from the long-term mean temperature curve $\left(\mathrm{t} \pm 0.5 \mathrm{C}^{\circ}\right)$. $\mathrm{BF}$ : hatching curve, $\mathrm{t}+0.5 \mathrm{C}^{\circ} ; \mathrm{AE}$ : hatching curve, $\mathrm{t}-0.5 \mathrm{C}^{\circ}$; DH: metamorphosis curve, $\mathrm{t}+0.5 \mathrm{C}^{\circ}$; $\mathrm{CG}$ : metamorphosis curve, $\mathrm{t}-0.5 \mathrm{C}^{\circ}$

(Fig. 3). All 5 larval stages therefore should be expected to occur in the field from the beginning of July.

The main hatching activity of Carcinus maenas can be assumed to last from end of May to mid-July. Following the predictions of the present model, these larvae will metamorphose during a period of about 30 d, between mid-July and mid-August (Fig. 3).

Fig. 5 shows the range of temperature-dependent larval dynamics in field temperatures deviating $\pm 0.5 \mathrm{C}^{\circ}$ from the long-term mean temperature curve. Hatching and metamorphosis curves represent minimum and maximum time spans in larval development.

The reliability of these model predictions may be tested by rearing larvae under varying temperatures, simulating natural dynamics (Table 3). Under such conditions eggs were incubated and larvae hatched on $27 \mathrm{May}$, when water temperature had reached $10^{\circ} \mathrm{C}$. The total larval development lasted $51.9 \pm 1.0 \mathrm{~d}$, while temperature in the rearing vials increased to $16^{\circ} \mathrm{C}$. This experiment was simulated by means of the present model: development of larvae which hatched on 27 May was predicted to last $51 \mathrm{~d}$, while in situ temperature rose from 10 to $15.8^{\circ} \mathrm{C}$ (Table 3).

\section{DISCUSSION}

Data obtained on Carcinus maenas larvae reared under a simulated natural temperature regime correspond satisfactorily with predictions made by the
Table 3. Carcinus maenas. Comparison of experimental results and extrapolation of larval development in nature. A: laboratory development of larvae reared under a simulated in situ temperature regime (hatching on $27 \mathrm{May}$ ). B: prediction of in situ development by means of the present model. $\overline{\mathrm{x}}$ : mean values in days, $\pm 95 \%$ confidence intervals; cum. cummulative durations; $\mathrm{n}$ : number of individuals

\begin{tabular}{|crrr|}
\hline & \multicolumn{2}{c}{$\mathrm{A}$} & $\mathrm{B}$ \\
\hline & $\overline{\mathrm{x}}$ & \pm & \\
\hline Zoea 1 & 12.00 & 0.32 & 10 \\
Zoea 2 & 8.80 & 0.42 & 8 \\
cum. & 20.51 & 0.47 & 18 \\
Zoea 3 & 7.97 & 0.66 & 8 \\
cum. & 28.48 & 0.87 & 26 \\
Zoea 4 & 9.08 & 0.36 & 9 \\
cum. & 37.26 & 0.94 & 35 \\
Megalopa & 14.62 & 0.57 & 16 \\
cum. & 51.91 & 0.98 & 51 \\
& $\mathrm{n}=50$ & \\
\hline
\end{tabular}

model employed. Hence, the model is considered useful.

Plankton samples from Helgoland waters were examined for Carcinus maenas larvae every other day during 1984 (Steiff pers. comm.). Times when respective stages were first found in the plankton correspond very well with predictions made by the present paper: zoea 1 (11 May), zoea 2 (25 May), zoea 3 (14 Jun), zoea 4 (15 Jun), megalops (27 Jun). Subsequently, all 5 larval stages were found in the samples until the end of the observation period on 9 July. Williamson (1902) assumed the hatching season of $C$. maenas to last from March to the end of July.

It is interesting to know how and to what extent varying environmental factors influence larval dynamics in the field. What happens after a possible acute temperature increase or decrease? The present model indicates that this depends very much on the time of year when such disturbances of the typical long-term temperature course may occur.

Early in the year, when overall in situ temperature is rising, all factors delaying development, such as lower temperatures and depletion of food, will reveal more minor effects than later in the year when in situ temperature is falling. Higher temperatures and good feeding conditions enhance larval development of Carcinus maenas (Dawirs 1984); even more so while overall in situ temperatures are increasing.

It appears that larval development in the field is mainly controlled by temperature dynamics. Larvae hatching on subsequent days during the assumed main hatching period (beginning of Jun to mid-Jul) show accelerated development. Metamorphosis of these lar- 
vae thus is focussed on a period between mid-July and mid-August. Similarly, but even more pronounced, this terminal settling appears in Hyas araneus development (Anger \& Nair 1979, Anger 1983). Here main hatching activity occurs at times of minimum field temperature (mid-Feb until mid-Mar), followed by an invasion-like settlement between the beginning and middle of June. Against a background of rising field temperatures, larval occurrence in the plankton appears to be stabilized. Thus main settlement of juvenile crabs is guaranteed to occur during the particular period of the year which is most advantageous for further development.

There is an advantage for Carcinus maenas planktotrophic larvae in developing early in the year when adequate provision of suitable food organisms is assured. Larvae which metamorphose in July-August can develop through 6 juvenile crab stages and grow to about $8 \mathrm{~mm}$ (average carapace width) during the same year (Klein Breteler 1975). This gives them a good start in the following spring, since they will stay in hibernation during winter.

Assumptions made by the present model agree with observations by Klein Breteler (1975). He found that settling of Carcinus maenas megalops in the Netherland Wadden Sea intertidal region begins in early July and may last until November. Klein Breteler recognized 2 peaks of larval settlement: the first in July was more distinct than the latter, in fall. This is probably due to 2 separate periods of egg production (Broekhuysen 1937). Eggs laid late in fall pass the winter attached to the pleopods of females. Directly after hatching of the larvae in June-July adult crabs copulate again. Embryonic development of $C$. maenas is temperature-dependent and lasts between 22 and $100 \mathrm{~d}$ (Dries \& Adelung 1976). Occurrence of larvae late in the year can thus be explained. Nevertheless, they are found in lower quantities than in spring (Rees 1954, Klein Breteler 1975), and are released into the ecologically less favourable temperature climate. Larvae which hatch from summer eggs, therefore, can be assumed to play only a minor role in the recruitment of C. maenas.

It seems important to determine the abundance of Carcinus maenas larvae throughout the year (Rees 1954, 1955, Ritz 1972, Lough 1976). Such data, together with the more qualitative implications of the present paper, should provide a good account of the dynamics and ecological role of C. maenas in the pelagic ecosystem of the German Bight.
Acknowledgements. I thank Dr. E. Wahl and Mr. M. Janke for providing Artemia nauplii; Mrs. F. Schorn for technical assistance; Mr. Jonathan A. Selzer for correcting, and Mrs. M. Rülicke for typing, the manuscript.

\section{LITERATURE CITED}

Anger, K., Nair, K. K. C. (1979). Laboratory experiments on the larval development of Hyas araneus (Decapoda, Majidae). Helgoländer wiss. Meeresunters. 32: 36-54

Anger, K. (1983). Temperature and the larval development of Hyas araneus L. (Decapoda: Majidae); extrapolation of laboratory data to field conditions. J. exp. mar. Biol. Ecol. 69: 203-215

Broekhuysen, G. J., jr. (1937). On development, growth and distribution of Carcinides maenas (L.). Archs néerl. Zool. 2: $257-399$

Dawirs, R. R. (1979). Effects of temperature and salinity on larval development of Pagurus bernhardus (Decapoda, Paguridae). Mar. Ecol. Prog. Ser. 1: 323-329

Dawirs, R. R. (1982a). Laboruntersuchungen zur larvalen Entwicklung von Carcinus maenas L. (Decapoda, Paguridae) und Pagurus bernhardus L. (Decapoda, Paguridae). Dissertation, University of Kiel

Dawirs, R. R. (1982b). Methodical aspects of rearing decapod larvae Pagurus bernhardus (Paguridae) and Carcinus maenas (Portunidae). Helgoländer Meeresunters. 35: $439-464$

Dawirs, R. R. (1984). Influence of starvation on larval development of Carcinus maenas L. (Decapoda, Portunidae). J exp. mar. Biol. Ecol. 80: 47-66

Dries, M., Adelung, D. (1976). Neue Ergebnisse über die Aufzucht von Carcinus maenas im Laboratorium. Mar. Biol. 38: 17-24

Harms, J. (1982). Untersuchungen zur Larvalentwicklung und zum Wachstum von Seepocken der Deutschen Bucht. Thesis, Technische Hochschule Darmstadt, Germany

Klein Breteler, W. C. M. (1975). Growth and molting of juvenile shore crabs Carcinus maenas in a natural population. Neth. J. Sea Res. 9: 86-99

Lough, R. G. (1976). Larval dynamics of the Dungeness crab, Cancer magister off the central Oregon coast, 1970-71. Fish. Bull. U. S. 74: 353-376

Rees, C. B. (1954). Continuous plankton records: The decapod larvae in the North Sea, 1947-1949. Bull. mar. Ecol. 3: $157-184$

Rees, C. B. (1955). Continuous plankton records: The decapod larvae in the North Sea, 1950-51. Bull. mar. Ecol. 4:69-80

Ritz, D. A. (1972). Factors effecting the distribution of rocky lobster larvae (Panilurus longipes cygnus) with reference to variability of plankton net catches. Mar Biol. 13: 309-317

Weigel, H.-P. (1978). Temperature and salinity observations from Helgoland Reede in 1967. Annls Biol. Copenh. 33: 35

Williamson, H. C. (1902). On the larval and early young stages and rate of growth of the shore-crab /Carcinus maenas) Leach. Rep. Fish. Bd Scotl., Sci. Invest. 21. $136-179$ 